\title{
norden
}

\section{Kuinka unelmat toteutuvat}

Yrittäjyyskasvatuksen osaamistavoitteet ja didaktiset periaatteet Pohjoismaissa

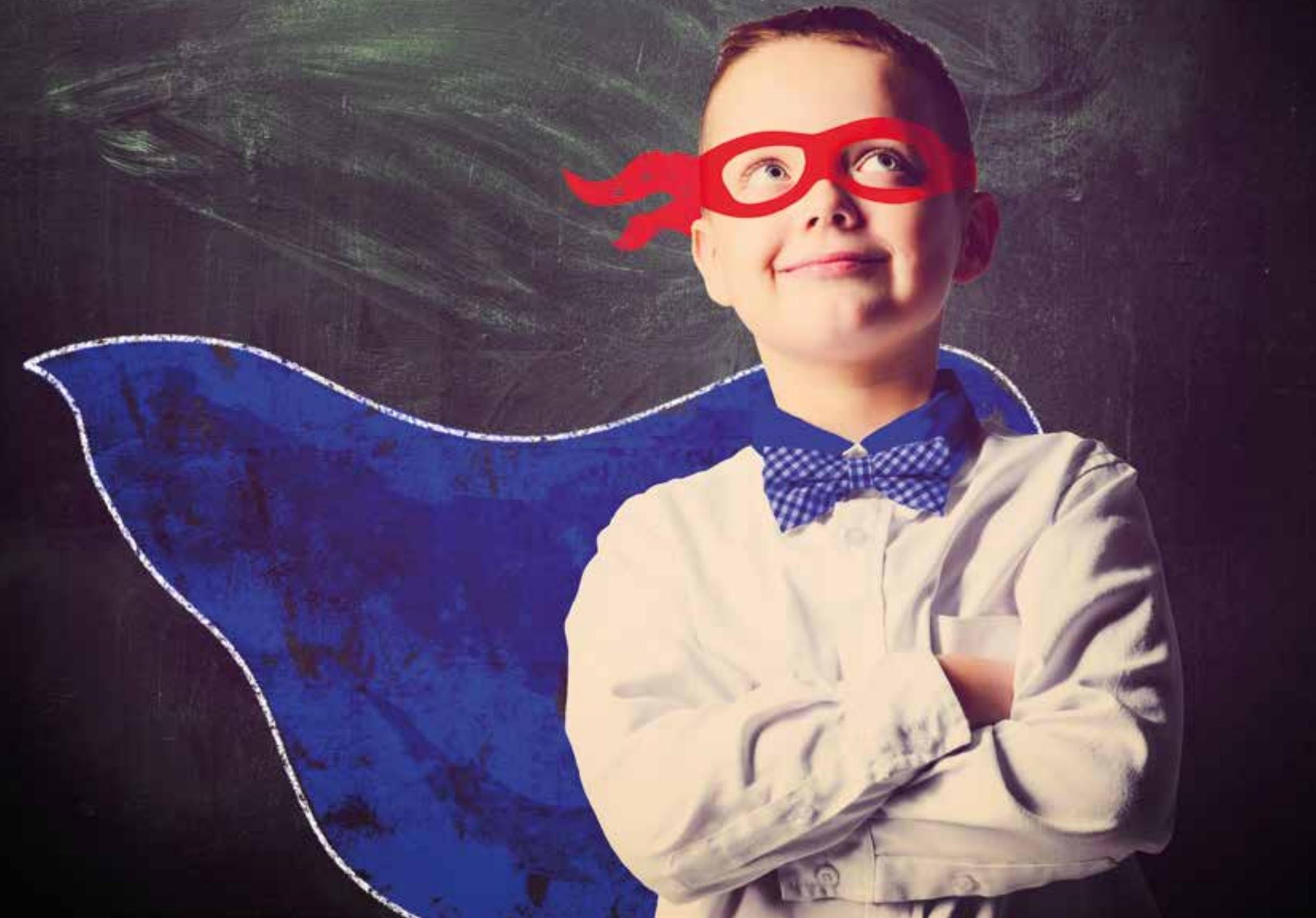




\section{Kuinka unelmat toteutuvat}

Yrittäjyyskasvatuksen osaamistavoitteet ja didaktiset periaatteet Pohjoismaissa

ISBN 978-92-893-4484-5 (PRINT)

ISBN 978-92-893-4485-2 (PDF)

http://dx.doi.org/10.6027/ANP2016-711

ANP 2016:711

(C) Pohjoismaiden ministerineuvosto 2016

Ulkoasu: Gitte Wejnold

Kannen valokuva: SignElements.com

Valokuva: SignElements.com
Pohjoismaiden ministerineuvosto on myöntänyt tukea raportin julkaisemiseen. Raportin sisältö ei välttämättä edusta Pohjoismaiden ministerineuvoston kantaa, näkemyksiä tai suosituksia.

\section{www.norden.org/nordpub}

\section{Pohjoismainen yhteistyö}

Pohjoismainen yhteistyö on yksi maailman laajimpia alueellisia yhteistyömuotoja. Yhteistyön piiriin kuuluvat Islanti, Norja, Ruotsi, Suomi ja Tanska sekä Ahvenanmaa, Färsaaret ja Grönlanti.

Pohjoismaista yhteistyötä tehdään politiikan, talouden ja kulttuurin aloilla tärkeänä osana eurooppa-laista ja kansainvälistä yhteistyötä. Pohjoismaisen yhteisön tavoitteena on vahva Pohjola vahvassa Euroopassa.

Pohjoismainen yhteistyö pyrkii vahvistamaan pohjoismaisia ja alueellisia etuja ja arvoja globaalissa maailmassa. Maiden yhteiset arvot lujittavat osaltaan Pohjolan asemaa yhtenä maailman innovatiivi-simmista ja kilpailukykyisimmistä alueista.

\section{Pohjoismaiden ministerineuvosto}

Ved Stranden 18

DK-1061 København K

Puhelin (+45) 33960200

www.norden.org 


\section{Kuinka unelmat toteutuvat}

Yrittäjyyskasvatuksen osaamistavoitteet ja didaktiset periaatteet Pohjoismaissa 


\section{Johdanto}

Pohjoismaiden ministerineuvosto on tehnyt monivaiheista työtä yrittäjämäisyyden ja yrittäjyyskasvatuksen tukemiseksi Pohjoismaissa. Kansainvälistyminen, teknologiakehitys, muutosnopeus ja väestön ikärakenteen muutokset asettavat haasteita niin pohjoismaiselle hyvinvointimallille kuin yksittäiselle ihmisellekin.

Sen vuoksi myös koulutusjärjestelmien on pystyttävä valmistamaan koululaisia ja opiskelijoita elämään, jossa he voivat aktiivisesti osallistua tulevaisuuden muovaamiseen.

Pohjoismaiden ministerineuvoston palkittu raportti "Entrepreneurship Education in the Nordic countries"1

ja EU:n raportti "Final Report of the Thematic Working Group on Entrepreneurship Education"2 tuovat esille tarpeen kehittää osaamiskehys, joka voi toimia sillanrakentajana strategian, johtamisen, käytännön ja oppimisen välillä. Osaamiskehys auttaa myös kehittämään opetusta ja havainnollistaa eroa yrittäjyyskasvatusta saaneen oppilaan ja muiden oppilaiden välillä. Lisäksi osaamiskehys mahdollistaa sen, että opetuksen lähtökohdaksi voidaan ottaa se, mitä pitää oppia, eikä erillisiä toimintoja tai prosesseja. Tässä julkaisussa esitelty osaamiskehys pyrkii vastaamaan tarpeeseen pohjoismaisten kouluperinteiden ja Pohjoismaissa samanaikaisesti kehittyneen laajamerkityksisen yrittäjyyskäsityk- sen pohjalta. Koulussa annettavan yrittäjyyskasvatuksen tavoitteena Pohjoismaissa on antaa oppilaille taitoja, jotka ovat käyttökelpoisia monissa eri yhteyksissä henkilökohtaisessa, sosiaalisessa ja yhteiskunnallisessa elämässä.

Osaamiskehys on suunnattu monille eri toimijoille. Se on tarkoitettu ennen kaikkea työvälineeksi opettajille ja käytännön työtä tekeville, jotka voivat löytää siitä osaamis- ja oppimistavoitteita sekä didaktisia periaatteita opetukseen. Osaamiskehystä voivat hyödyntää myös päätöksentekijät, jotka säätävät lakeja ja luovat puitteet yrittäjyyskasvatuksen toteuttamiselle. Se on suunnattu myös rehtoreille, joiden tehtävänä on huolehtia koulun rakenteiden toimivuudesta, luoda oppimisympäristöjä ja kehittää pedagogiikkaa siten, että yrittäjyyskasvatuksesta tulee kiinteä osa peruskoulua.

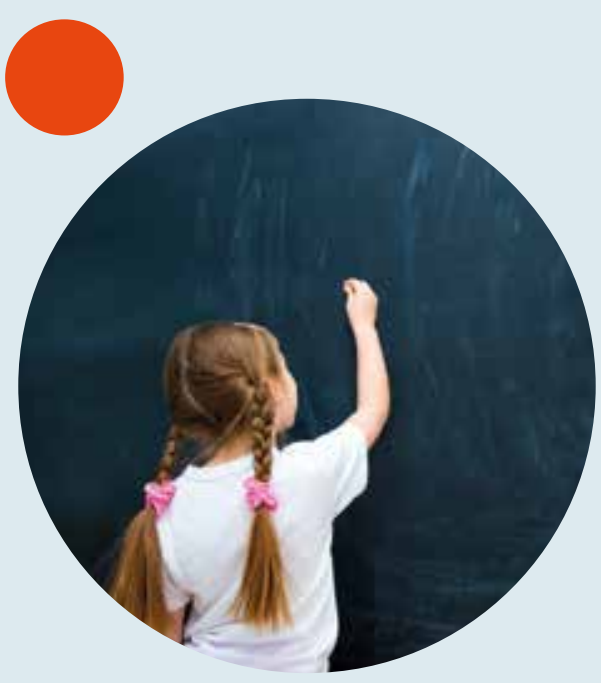




\section{Pohjoismaiset erityispiirteet}

Pohjoismaiden koululaitosten välillä on kansallisia eroja, mutta myös yhteisiä piirteitä on paljon. Niitä ovat muun muassa yleissivistyksen merkitys, kansanvalistusliikkeen vaikutus ja uudistuspedagogiikka. Viime vuosina keskeisellä sijalla ovat olleet kansainväliset vertailut sekä tutkimustieto- ja oppimistavoiteperusteinen opetus.

\section{Sivistys}

Julkisten koulutusjärjestelmien perustamisen myötä sivistyksestä on tullut osa pohjoismaista koulu- ja koulutusnäkemystä. Yleissivistävään koulutukseen kuuluu myös se, että on oppiaineita ja osaamista pitemmälle menevää koulutusta, joka koskee periaatteessa keskeneräistä prosessia tulla elinkelpoiseksi ja täysivaltaiseksi, tiettyyn kulttuuriympäristöön kuuluvaksi ihmiseksi. Yleissivistys on pohjoismaisissa kouluissa yksi koulujen yleistavoitteista. Yleissivistys ja sivistysihanteet eivät kuitenkaan ole muuttumattomia suureita, vaan ne vaihtelevat aikojen kuluessa poliittisten ja kulttuurikontekstien sekä pedagogisten ja filosofisten virtausten mukana. Yleissivistys on siten dynaaminen käsite, jossa pääpaino on vaihdellut henkilökohtaisen kasvun ja ennalta määriteltyjen tiedollisten tavoitteiden välillä. ${ }^{3}$

${ }^{1}$ Pohjoismaiden ministerineuvosto (2012).

${ }^{2}$ Euroopan komissio (2015).

${ }^{3}$ Gustavsson (1998) Dannelse i vor tid, Forlaget KLIM. 


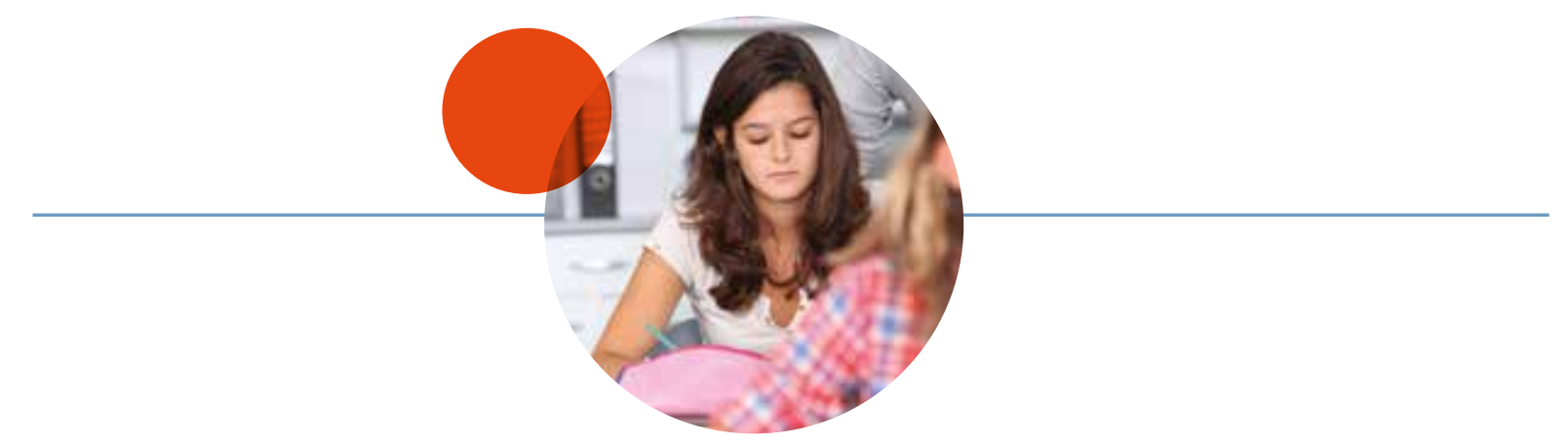

Pohjoismaiset demokratiat ja hyvinvointivaltiot ovat näin ollen syntyneet läheisessä vuorovaikutuksessa demokraattisen sivistysihanteen kanssa. Niinpä oppilaiden on tärkeää oppia ottamaan kantaa, toimimaan, edistämään demokraattista yhteiskuntaa ja osallistumaan demokraattisina kansalaisina. Sivistyskäsitteeseen sisältyy myös itsemääräämiskyky sekä kyky kantaa sosiaalista vastuuta ja olla aktiivinen toimija yhteiskunnassa. Tämä näkökulma on hyvin lähellä pohjoismaista yrittäjyyskasvatusta ja tässä raportissa esiteltyä osaamiskehystä.

Sivistyskäsitteen ongelmana on, että tapa ymmärtää sitä vaihtelee. Lisäksi se nähdään usein tiedollisen osaamisen vastapainona, vaikka tiedollinen osaaminen on aina kuulunut yleissivistykseen. Usein on myös epäselvää, mitä pitää opettaa ja vastaavasti mitä pitää oppia ollakseen "sivistynyt". Tämän raportin osaamiskehys on yritys konkretisoida ja havainnollistaa joitakin yrittäjyyskasvatuksen elementtejä, jotka jo nykyisellään sisältyvät koulujen tavoitteisiin.

\section{Uudistuspedagogiikka}

Uudistuspedagogiikalla on ollut huomattava vaikutus pohjoismaiseen koulutusajatteluun. Sen vaikutuksesta muun muassa autoritäärisen koulun kova kuri ja ulkoluku ovat kadonneet. Vaikka nykyisin keskitytään osaamiseen ja mitattavuuteen, opetus on edelleen lapsikeskeistä ja lähtökohtana ovat useimmiten oppilaiden tarpeet ja kiinnostuksen kohteet. Oppilaat ovat myös aktiivinen osa oppimisprosessia, ja osallistuminen projekteihin, ryhmätöihin ja oppiaineryhmien välisiin tehtäviin on osa pohjoismaista kouluarkea. Yhdessä kansanvalistusliikkeiden tekemän työn kanssa tästä on kehittynyt pohjoismaista koulua luonnehtiva “itsestäänselvyys”, joka tarkoittaa opettajan ja oppilaan välistä epävirallista ja tasa-arvoista suhdetta sekä oppilaiden motivaation, tahdon ja kiinnostuksen kohteiden huomioimista opetuksessa. ${ }^{4}$

Vapauttavan ja uudistavan pedagogiikan kausi on ollut yhtä voittokulkua, ja ongelmana ei nyt olekaan vapauden puute, joka vapauspedagogiikan piti korjata, vaan se, mihin me vapautta ja vapautumista oikein käytämme. ${ }^{5}$ Yrittäjyyskasvatus voidaan nähdä uudistuspedagogisten ajatusten jatkumona, koska sen tarkoituksena on tukea oppilaiden toimintakykyä yhteiskunnassa, omasta elämästä ja urasta huolehtimista sekä aloitteellisuutta siten, että toiminta tuottaa kulttuurista, taloudellista ja sosiaalista lisäarvoa muille. ${ }^{6}$ Yrittäjyyskasvatus ei siis ole vapauttavaa klassisessa merkityksessä, vaan tarkoituksena on vahvistaa oppilaiden osaamista, jotta he pystyisivät vapaasti hyödyntämään elämässä ja maailmassa tarjolla olevia mahdollisuuksia.

\section{Oppimistavoitteet ja seuranta keskeisinä painoalueina}

Viime vuosina mitattavista oppiainetavoitteista ja kansainvälisistä vertailuista on tullut osa poliittista koulukeskustelua ja siten myös osa koulujen arkipäivää Pohjoismaissa. Samanaikaisesti tutkimukset, jotka osoittavat oppilaiden oppivan enemmän opetuksen perustuessa näkyviin oppimistavoitteisiin ja palautteeseen, ovat saaneet lisää painoarvoa. ${ }^{7}$ Tämä on johtanut moniin uudistuksiin koulujärjestelmissä sekä kouluja ja opettajia koskevissa vaatimuksissa. Muutos on tapahtunut samanaikaisesti yrittäjyysstrategioiden käyttöönoton kanssa. Ongelmana on se, että kun oppiaineita määritellään ja mitataan entistä enemmän, koulun yleistavoitteet yrittäjyyskasvatus mukaan lukien 


\section{Yrittäjyyskasvatuksen osaamistavoitteet}

Osaamiskehys perustuu tämänhetkiseen kansainväliseen tutkimukseen, pohjoismaisiin koulutavoitteisiin ja yrittäjyysstrategioihin. Viidestä Pohjoismaasta ja kolmelta itsehallintoalueelta koottu viiteryhmä on varmistanut, että osaamiskehystä voidaan käyttää kansallisissa olosuhteissa. Osaamiskäsitteen innoittajana on ollut Knud Illeris $^{8}$ ja hänen ajatustensa mukaisesti osaaminen ymmärretään seuraavasti:

\section{"Kokonaisvaltaisia älyllisiä ja emotionaalisia valmiuksia, taipumuksia ja kykyjä, jotka ovat yhteydessä mahdollisiin toiminta-alueisiin ja jotka toteutuvat tunnettuihin ja tuntemattomiin tilanteisiin liittyvien arviointien, päätösten ja toimintojen kautta."}

Kehys koostuu siten useista osaamisen aloista, joita tieto, taidot, tunteet ja henkilökohtaiset ominaisuudet tukevat.
Tieto ja taidot ovat lähtökohtaisesti konkreettisia, ja vaikka niitä ei aina voi mitata, niitä on kuitenkin mahdollista tarkkailla ja luokitella. Henkilökohtaisten ja subjektiivisten ominaisuuksien suhteen tilanne on toinen. Niitä ei voi opettaa, testata eikä arvioida. Esimerkiksi "sitkeys" on todennäköisesti tärkeä ominaisuus, jota ei voi opettaa, mutta sitä voi harjoitella opetuksessa käytettävien menetelmien ja toimintojen avulla. Tämä osa osaamiskehystä onkin enemmän riippuvainen menetelmästä ja didaktisesta lähestymistavasta kuin konkreettisemmat tietoon ja taitoihin liittyvät alueet.

\section{Tutkimus}

Tutkijat eivät ole yksimielisiä siitä, mitä tietoja, taitoja ja henkilökohtaisia ominaisuuksia yrittäjäosaaminen edellyttää. Yksimielisyyttä ei myöskään ole siitä, miten tätä osaamista voidaan kehittää. On kuitenkin joitakin keskeisiä alueita, jotka erottuvat selvästi ja jotka koskevat sekä opetuksen sisältöä että pedagogista muotoa. ${ }^{9}$ 
Niitä ovat:

- Toimintanäkökulman painottaminen ja oppilaiden konkreettisten toimien sekä aktiivisen osallistumisen ottaminen yrittäjyyskasvatuksen perustaksi.

- Luovuus ja taito nähdä, aistia ja luoda mahdollisuuksia, ongelmanratkaisutaidot, divergentti ajattelukyky ja kyky kokeilla tiedon eri muodoilla.

- Kulttuuria, ympäröivää maailmaa ja ulkopuolisia toimijoita koskeva tieto ja ymmärrys sekä vuorovaikutus niiden kanssa.

- Oppilaiden subjektiivinen usko ja luottamus omiin mahdollisuuksiin ja kykyyn toimia maailmassa ja toteuttaa unelmia ja visioita, mukaan lukien kestävyys ja kyky toimia epävarmoissa tilanteissa.

\section{Pohjoismaiset strategiat ja sivistykselliset tavoitteet}

Opetuksen yleistavoitteisiin ja kansallisiin yrittäjyysstrategioihin Pohjoismaissa sisältyy useita tieto-, taito- ja osaamistavoitteita, jotka liittyvät suoraan tai epäsuorasti yrittäjyyteen. Osa niistä koskee ulkoisia asioita, joista oppilailla edellytetään olevan tietoa: luovat työmenetelmät, liiketoiminnan kehittäminen, talous, projektinhallinta, verkostot. Osa on asioita, jotka oppilaiden on hallittava: aloitteenteko, vastuun ottaminen, ideoiden muuntaminen toiminnaksi, päätöksenteko, viestintä, yhteistyö ja ongelmanratkaisu. Muut tavoitealueet ovat sisäisiä. Kyse on siis emotionaalisista ja henkilökoh- taisista ominaisuuksista, kuten avoin suhtautuminen mahdollisuuksiin, sitkeys ja kestävyys, uteliaisuus, itseluottamus, luovuutta ja rohkeutta riskinottoon, mielikuvituksen käyttäminen rajojen ylittämiseen. Lisäksi on joitakin ohjeellisia tai eettisiä tavoitteita, kuten kestävän tulevaisuuden edistäminen.

\section{Viiteryhmän panos}

Viiteryhmältä saatiin suuri joukko tietoihin, taitoihin ja osaamiseen liittyviä ehdotuksia. Kuten opetuksen yleistavoitteissa tässäkin on kyse hyvin vaihtelevista tieto-, taito- ja osaamistavoitteista, joista jotkut ovat ulkoisia ja jotkut sisäisiä. Esimerkiksi: minä itse yrittäjämäisenä henkilönä, yhteiskunnan rakenne ja toiminta, itseni ja ideoideni esittely, tarpeiden näkeminen ja ratkaisujen löytäminen, epävarmuuden luova käsittely, mahdollisuuksien tunnistaminen ja ennakoiva toiminta sekä paikallisyhteisön, maan ja maailman tuntemus.

Huomiota on vaihtelevassa määrin kiinnitetty myös "opiskelussa edistymiseen ja osaamistasojen luokitteluun" (Tanska), erityiseen "pedagogisen yrittäjyyden" muotoon (Norja) ja erityiseen "yrittäjämäisen oppimisen" lähestymistapaan (Ruotsi). Erilaiset lähestymistavat osoittavat, että suhteellisen samankaltaiset pohjoismaiset strategiat ovat tuottaneet suuren määrän erilaisia toimintoja ja käytäntöjä.

${ }^{8}$ Illeris (2013) Kompetence - Hvad, hvorfor, hvordan?, Samfundslitteratur.

${ }^{9}$ Nybye \& Rasmussen (2013) Progressionsmodel for innovations og entreprenørskabsundervisning, Fonden for Entreprenørskab. 


\section{Osaamiskehys}

Yrittäjäosaaminen

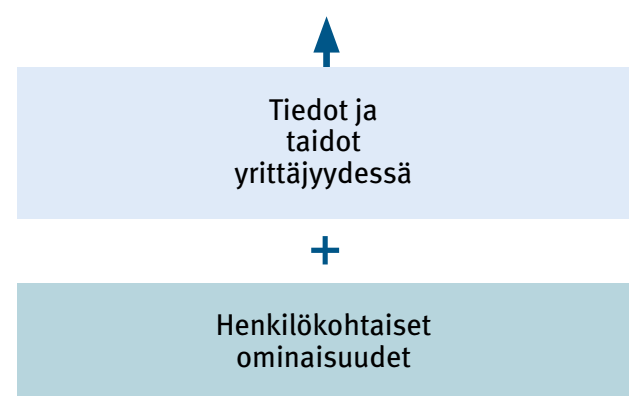

Tutkimustulosten, pohjoismaisten osaamistavoitteiden ja viiteryhmän panosten pohjalta muotoutuu neljä osaamisaluetta, joista kolmen voidaan katsoa perustuvan tietoon ja taitoihin. Neljäs osaamisalue koskee henkilökohtaisia ominaisuuksia ja toimii perustana oppilaan panostuksille muilla osaamisalueilla. Esimerkiksi erilaisten toimintojen toteuttaminen ympäröivässä maailmassa edellyttää rohkeutta, vastuunottoa, virheiden hyväksymistä jne. Toisaalta henkilökohtaiset ominaisuudet eivät itsessään välttämättä takaa laadukasta toimintaa, yrittäjämäistä osaamista tai yleissivistystä.

1. Toiminnallinen osaaminen: suunnittelu, jäsentäminen, toteutus, yhteistyö, viestintä, talousasioiden ja resurssien käytön hallinta.

2. Luova osaaminen: luovuus, rajojen ylittäminen, divergentti ja monialainen ajattelu, unelmointi, aistiminen, kokeellisuus, ongelmien ratkaisu ja arviointi.
3. Toimintaympäristöosaaminen: kulttuuritieto, globalisaatio, yhteiskunnalliset suuntaukset, liiketoimintaosaaminen, sosiaaliset olot, verkostot, kyky ymmärtää kompleksista nykyaikaa ja liikkua siinä. Tapamme ymmärtää maailmaa ja elinympäristöämme sekä niistä meihin kohdistuvia vaikutteita.

4. Henkilökohtaiset ominaisuudet: rohkeus, itseluottamus, sitkeys, kompleksisuuden ja epävarmuuden sietäminen, virheiden hyväksyminen, aloitekyky, vastuunotto ja itsenäisyys.

Yrittäjäosaaminen on siten toiminnallisten, luovien ja toimintaympäristöä koskevien tietojen ja taitojen tuotos, joka edellyttää tiettyjä henkilökohtaisia ominaisuuksia.

Osaamiskehys on kolmetasoinen: Vuosiluokka 3/aloitus, vuosiluokka 6/välivaihe ja vuosiluokka 9/lopetus. Tiedot, taidot ja osaaminen kuvaavat kaikilla kolmella tasolla ihannetilannetta ja lopputavoitetta. 


\section{3. vuosiluokka}

\begin{tabular}{|c|c|c|c|c|c|}
\hline \multicolumn{2}{|c|}{$\begin{array}{l}\text { Toiminnallinen osaaminen } \\
\text { Oppilas ratkaisee tehtäviä yhteistyössä } \\
\text { muiden kanssa ja toteuttaa tuen avulla } \\
\text { yksinkertaisia projekteja koulussa ja } \\
\text { lähiympäristössä }\end{array}$} & \multicolumn{2}{|c|}{$\begin{array}{l}\text { Luova osaaminen } \\
\text { Oppilas pystyy kokeelliseen ja tutkivaan } \\
\text { työskentelyyn yksinkertaisissa luovissa } \\
\text { prosesseissa ja osaa tarkastella tuloksia } \\
\text { oppiaineesta saatujen perustietojen } \\
\text { pohjalta }\end{array}$} & \multicolumn{2}{|c|}{$\begin{array}{l}\text { Toimintaympäristöosaaminen } \\
\text { Oppilaalla on alustava ymmärrys omasta } \\
\text { identiteetistä ja kulttuuritaustasta ja hän } \\
\text { selviää helpoista tilanteista paikallis- } \\
\text { yhteisössä }\end{array}$} \\
\hline Taito, osaa & Tietoa & Taito, osaa & Tietoa & Taito, osaa & Tietoa \\
\hline $\begin{array}{l}\begin{array}{l}\text { Osallistua } \\
\text { yksinkertaisiin } \\
\text { projekteihin }\end{array} \\
\text { Osallistua yksin- } \\
\text { kertaisiin yhteis- } \\
\text { työhankkeisiin } \\
\text { Esitellä omia } \\
\text { tuloksia ja tuot- } \\
\text { teita koulussa ja } \\
\text { lähiympäristössä } \\
\text { Ottaa yhteyksiä } \\
\text { henkilökohtaisiin } \\
\text { verkostoihin } \\
\text { Käyttää työssä } \\
\text { yksinkertaisia } \\
\text { visualisointeja ja } \\
\text { malleja }\end{array}$ & $\begin{array}{l}\text { Suunnittelusta ja } \\
\text { tavoitteista } \\
\text { Yhteistoiminnasta } \\
\text { muiden kanssa } \\
\text { Viestinnästä ja } \\
\text { yksinkertaisista } \\
\text { esittelytavoista } \\
\text { Henkilökohtaises- } \\
\text { ta verkostosta } \\
\text { Esittelyistä ja } \\
\text { malleista }\end{array}$ & $\begin{array}{l}\text { Käyttää mielikuvi- } \\
\text { tusta ja luovuutta } \\
\text { tunneilla ja } \\
\text { tehtävissä } \\
\text { Yhdistellä eri } \\
\text { alojen tietoa } \\
\text { Leikkiä tiedolla } \\
\text { Osallistua yksin- } \\
\text { kertaisiin ideointi- } \\
\text { prosesseihin } \\
\text { Osallistua ideoi- } \\
\text { den arviointikes- } \\
\text { kusteluihin } \\
\text { Käyttää aistimaa- } \\
\text { ilman käsitteitä ja } \\
\text { kuvakieltä }\end{array}$ & $\begin{array}{l}\text { Mielikuvituksesta } \\
\text { ja luovuudesta } \\
\text { Yksinkertaisista } \\
\text { luovista proses- } \\
\text { seista } \\
\text { Yksinkertaisesta } \\
\text { ideoinnista } \\
\text { Aisteista ja } \\
\text { yksinkertaisesta } \\
\text { estetiikasta }\end{array}$ & $\begin{array}{l}\text { Kuvailla omaa } \\
\text { kulttuuria } \\
\text { Käyttää rahakäsi- } \\
\text { tettä yksinkertai- } \\
\text { sissa matemaatti- } \\
\text { sissa laskelmissa } \\
\text { Keskustella } \\
\text { lähiympäristöön } \\
\text { liittyvistä mah- } \\
\text { dollisuuksista ja } \\
\text { haasteista }\end{array}$ & $\begin{array}{l}\text { Omasta ja muista } \\
\text { kulttuureista } \\
\text { Rahakäsitteestä } \\
\text { Vapaa-ajasta ja } \\
\text { työelämästä } \\
\text { Lähiympäristön } \\
\text { yrityksistä ja } \\
\text { laitoksista }\end{array}$ \\
\hline
\end{tabular}




\section{6. luokka}

\begin{tabular}{|c|c|c|c|c|c|}
\hline \multicolumn{2}{|c|}{$\begin{array}{l}\text { Toiminnallinen osaaminen } \\
\text { Oppilas tekee yhteistyössä muiden kans- } \\
\text { sa aloitteita konkreettisista projekteista } \\
\text { sekä suunnittelee, organisoi ja toteuttaa } \\
\text { niitä }\end{array}$} & \multicolumn{2}{|c|}{$\begin{array}{l}\text { Luova osaaminen } \\
\text { Oppilas työskentelee itsenäisesti, } \\
\text { kokeellisesti ja tutkivasti luovissa proses- } \\
\text { seissa sekä arvioi tuloksia tietojensa ja } \\
\text { esteettisten kriteerien perusteella }\end{array}$} & \multicolumn{2}{|c|}{$\begin{array}{l}\text { Toimintaympäristöosaaminen } \\
\text { Oppilas ymmärtää oman identiteettinsä } \\
\text { ja kulttuuritaustansa ja osaa sen pohjalta } \\
\text { liikkua erilaisissa teknisissä, taloudel- } \\
\text { lisissa, kulttuurisissa ja sosiaalisissa } \\
\text { konteksteissa }\end{array}$} \\
\hline Taito, osaa & Tietoa & Taito, osaa & Tietoa & Taito, osaa & Tietoa \\
\hline $\begin{array}{l}\text { Kuvata epävar- } \\
\text { muutta projektien } \\
\text { yhteydessä } \\
\text { Osallistua aktiivi- } \\
\text { sesti projekteihin } \\
\text { Käyttää hen- } \\
\text { kilökohtaista } \\
\text { verkostoa } \\
\text { Muodostaa yhteis- } \\
\text { työsuhteita } \\
\text { Esitellä tuloksia ja } \\
\text { projekteja }\end{array}$ & $\begin{array}{l}\text { Yksinkertaisesta } \\
\text { projektinhallin- } \\
\text { nasta, suunnitte- } \\
\text { lusta, riskeistä ja } \\
\text { resursseista } \\
\text { Yksinkertaisista } \\
\text { yhteistyömuo- } \\
\text { doista } \\
\text { Viestinnästä, } \\
\text { esittelytavoista ja } \\
\text {-keinoista. } \\
\text { Henkilökohtaises- } \\
\text { ta ja koulupohjai- } \\
\text { sesta verkostosta } \\
\text { Malleista, } \\
\text { symboleista ja } \\
\text { visuaalisesta } \\
\text { ilmaisusta }\end{array}$ & $\begin{array}{l}\begin{array}{l}\text { Yhdistää tiedon- } \\
\text { aloja }\end{array} \\
\text { Kokeilla tiedolla } \\
\text { Osallistua osaami- } \\
\text { seen perustuvaan } \\
\text { ongelmanratkai- } \\
\text { suun } \\
\text { Työskennellä luo- } \\
\text { vissa prosesseissa } \\
\text { Osallistua ide- } \\
\text { ointiin } \\
\text { Keskustella ideoi- } \\
\text { den arvioinnista } \\
\text { Käyttää aistimaail- } \\
\text { man käsitteitä } \\
\text { Keskustella lähitu- } \\
\text { levaisuutta koske- } \\
\text { vista unelmista }\end{array}$ & $\begin{array}{l}\text { Mielikuvituksen ja } \\
\text { luovuuden käytös- } \\
\text { tä eri oppiainei- } \\
\text { den yhteydessä } \\
\text { Luovista proses- } \\
\text { seista } \\
\text { Degeneraation } \\
\text { muodoista } \\
\text { Aisteista ja este- } \\
\text { tiikasta }\end{array}$ & $\begin{array}{l}\text { Vertailla kulttuure- } \\
\text { ja toisiinsa } \\
\text { Keskustella maa- } \\
\text { ilmassa olevista } \\
\text { mahdollisuuksista } \\
\text { ja haasteista } \\
\text { Keskustella siitä, } \\
\text { miten itse ymmär- } \\
\text { tää maailman } \\
\text { Laatia yksinkertai- } \\
\text { sia budjetteja } \\
\text { Kuvata yhteiskun- } \\
\text { nan taloutta ja } \\
\text { muita resursseja } \\
\text { Kuvata yrityksen } \\
\text { toimintaa }\end{array}$ & $\begin{array}{l}\text { Kulttuurien väli- } \\
\text { sistä eroista } \\
\text { Yhteiskunnan } \\
\text { rakenteesta ja } \\
\text { suuntauksista } \\
\text { Taloudesta ja eri } \\
\text { resursseista } \\
\text { Vapaa-ajasta, kou- } \\
\text { lu- ja työelämästä } \\
\text { Oman alueen } \\
\text { yrityksistä ja } \\
\text { laitoksista }\end{array}$ \\
\hline
\end{tabular}

\section{HENKILÖKOHTAISET OMINAISUUDET:}

Rohkeus ja tahto asettaa haasteita itselleen ja koulutovereilleen.

Vastuu omista ja yhteisistä projekteista.

Itseluottamus omiin kykyihin nähden.

Tehdä aloitteita yhdessä toisten kanssa.

Muutoshalukkuutta omien työtapojen, mielipiteiden ja näkemysten suhteen.

Sitkeys ja kestävyys pitkällä aikavälillä.

Omien ja muiden virheiden ja väärinymmärrysten hyväksyminen.

Epävarmuuden käsittely lyhyellä aikavälillä.

Tehtäviin ja haasteisiin keskittyminen pitkällä aikavälillä. 


\section{9. luokka}

\begin{tabular}{|c|c|c|c|c|c|}
\hline \multicolumn{2}{|c|}{$\begin{array}{l}\text { Toiminnallinen osaaminen } \\
\text { Oppilas tekee yhteistyössä muiden } \\
\text { kanssa aloitteita ja ottaa vastuuta konk- } \\
\text { reettisista projekteista sekä suunnitte- } \\
\text { lee, johtaa, organisoi ja toteuttaa niitä }\end{array}$} & \multicolumn{2}{|c|}{$\begin{array}{l}\text { Luova osaaminen } \\
\text { Oppilas työskentelee itsenäisesti, sinnik- } \\
\text { käästi, kokeellisesti ja tutkivasti luovissa } \\
\text { prosesseissa sekä arvioi tuloksia tietojen- } \\
\text { sa, kokemusten ja esteettisten kriteerien } \\
\text { perusteella }\end{array}$} & \multicolumn{2}{|c|}{$\begin{array}{l}\text { Toimintaympäristöosaaminen } \\
\text { Oppilas ymmärtää oman identiteettinsä } \\
\text { ja kulttuuritaustansa ja oppii sen pohjal- } \\
\text { ta toimimaan erilaisissa teknisissä, talou- } \\
\text { dellisissa, kulttuurisissa ja sosiaalisissa } \\
\text { konteksteissa sekä arvioimaan niitä }\end{array}$} \\
\hline Taito, osaa & Tietoa & Taito, osaa & Tietoa & Taito, osaa & Tietoa \\
\hline $\begin{array}{l}\text { Hallinnoida } \\
\text { projekteja yhdessä } \\
\text { muiden kanssa } \\
\text { Arvioida projek- } \\
\text { teihin liittyviä } \\
\text { epävarmuusteki- } \\
\text { jöitä ja riskejä } \\
\text { Muodostaa } \\
\text { erilaisia yhteistyö- } \\
\text { suhteita } \\
\text { Ottaa yhteyksiä } \\
\text { henkilökohtaisten } \\
\text { verkostojen ulko- } \\
\text { puolelle } \\
\text { Kehittää ja käyttää } \\
\text { omaa verkostoa } \\
\text { Esitellä tuloksia ja } \\
\text { projekteja tietylle } \\
\text { kohderyhmälle }\end{array}$ & $\begin{array}{l}\text { Projektin- } \\
\text { hallinnasta, } \\
\text { suunnittelusta, } \\
\text { sidosryhmistä, } \\
\text { riskeistä ja } \\
\text { resursseista } \\
\text { Yhteistyömuodo- } \\
\text { ista ja proses- } \\
\text { seista } \\
\text { Henkilö- } \\
\text { kohtaisista ja } \\
\text { ammatillisista } \\
\text { verkostoista } \\
\text { Viestinnästä, } \\
\text { esittelytavoista } \\
\text { ja -keinoista }\end{array}$ & $\begin{array}{l}\text { Yhdistää erilaisia } \\
\text { tiedonaloja } \\
\text { Kokeilla tiedolla ja } \\
\text { osaamisellaan } \\
\text { Ratkaista ongelmia } \\
\text { osaamisen perus- } \\
\text { teella } \\
\text { Jäsennellä ideointi- } \\
\text { prosesseja } \\
\text { Työskennellä } \\
\text { erilaisissa luovissa } \\
\text { prosesseissa } \\
\text { Keskustella ideoiden } \\
\text { arvioinnista } \\
\text { Käyttää aistikäsit- } \\
\text { teitä tiedonalojen } \\
\text { yhteydessä } \\
\text { Esittää unelmia ja } \\
\text { visioita tulevaisuu- } \\
\text { desta }\end{array}$ & $\begin{array}{l}\text { Mielikuvituksesta } \\
\text { ja luovuudesta } \\
\text { yhteiskunnassa } \\
\text { Luovista proses- } \\
\text { seista } \\
\text { Erilaisista ideoin- } \\
\text { titavoista } \\
\text { Aisteista ja este- } \\
\text { tiikasta } \\
\text { Luovuuden ja } \\
\text { tiedollisen osaa- } \\
\text { misen suhteesta }\end{array}$ & $\begin{array}{l}\text { Kuvailla ja verrata } \\
\text { kulttuureja toi- } \\
\text { siinsa } \\
\text { Kuvata globali- } \\
\text { saation mah- } \\
\text { dollisuuksia ja } \\
\text { haasteita } \\
\text { Laatia yksinkertai- } \\
\text { sia budjetteja } \\
\text { Analysoida ja ku- } \\
\text { vata resursseja } \\
\text { Kuvata yksinker- } \\
\text { taisia liiketoimin- } \\
\text { tamalleja } \\
\text { Haastaa tämän- } \\
\text { hetkistä maailman } \\
\text { ymmärtämistä }\end{array}$ & $\begin{array}{l}\text { Eri kulttuureista } \\
\text { Globalisaatiosta ja } \\
\text { sen seurauksista } \\
\text { Yhteiskunnan } \\
\text { rakenteesta, } \\
\text { suuntauksesta, } \\
\text { ongelmista ja } \\
\text { mahdollisuuksista } \\
\text { Työelämästä ja } \\
\text { uramahdollisuuk- } \\
\text { sista } \\
\text { Taloudesta ja } \\
\text { budjetista }\end{array}$ \\
\hline & $\begin{array}{r}\text { Itseluot } \\
\text { Aloit } \\
\text { Omien ja muiden } \\
\text { Epä } \\
\text { Keskittyminen }\end{array}$ & $\begin{array}{l}\text { HENKILÖKOHTAIS } \\
\text { keus ja tahto asettaa } \\
\text { Vastuu omista ja y } \\
\text { nus omiin arviointeihir } \\
\text { den tekeminen itsenäi } \\
\text { Halu muuttaa nykyisiä } \\
\text { keys ja kestävyys pitkä } \\
\text { heiden sekä väärinymn } \\
\text { rmojen ja monimutkais } \\
\text { keytyksiä sisältäviin t }\end{array}$ & $\begin{array}{l}\text { OMINAISUUDET: } \\
\text { steita itselleen ja m } \\
\text { sistä projekteista. } \\
\text { ykyihin ja potentiaa } \\
\text { ti ja yhdessä toister } \\
\text { ityksiään ja tapojaa } \\
\text { ja tauotetulla aikavä } \\
\text { rysten hyväksymine } \\
\text { tehtävien hahmott } \\
\text { äviin ja projekteihin }\end{array}$ & $\begin{array}{l}\text { e. } \\
\text { nähden. } \\
\text { nssa. } \\
\text { ä. } \\
\text { a niistä oppiminen. } \\
\text { inen. } \\
\text { källä aikavälillä. }\end{array}$ & \\
\hline
\end{tabular}


Yrittäjyysosaaminen ja pedagogiset käytännöt

Yrittäjyys ei ole oppiaine koulussa Pohjoismaissa, ja yrittäjyyteen liittyvien valmiuksien kehittäminen on sen vuoksi sisällytettävä muihin oppiaineisiin erityisenä yrittäjätaitojen koulutus- ja oppimispolkuna. Opettajien tulee näin ollen yhdistää yrittäjyyteen liittyvien tietojen ja taitojen kehittäminen koulun oppiaineisiin siten, että yrittäjyyskasvatuksesta tulee osa koulun arkipäivää. Koulun tulee samalla varmistaa, että oppilailla on mahdollisuus osallistua yhtäjaksoiseen yrittäjyyskasvatuspolkuun, jonka kuluessa tietoja ja taitoja voi harjaannuttaa lisäarvoa tuottavassa toiminnassa, jos mahdollista.

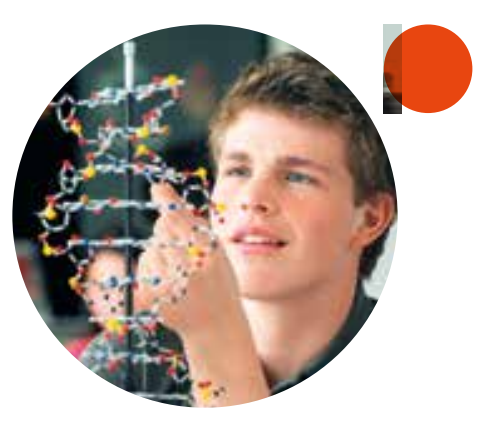

14 


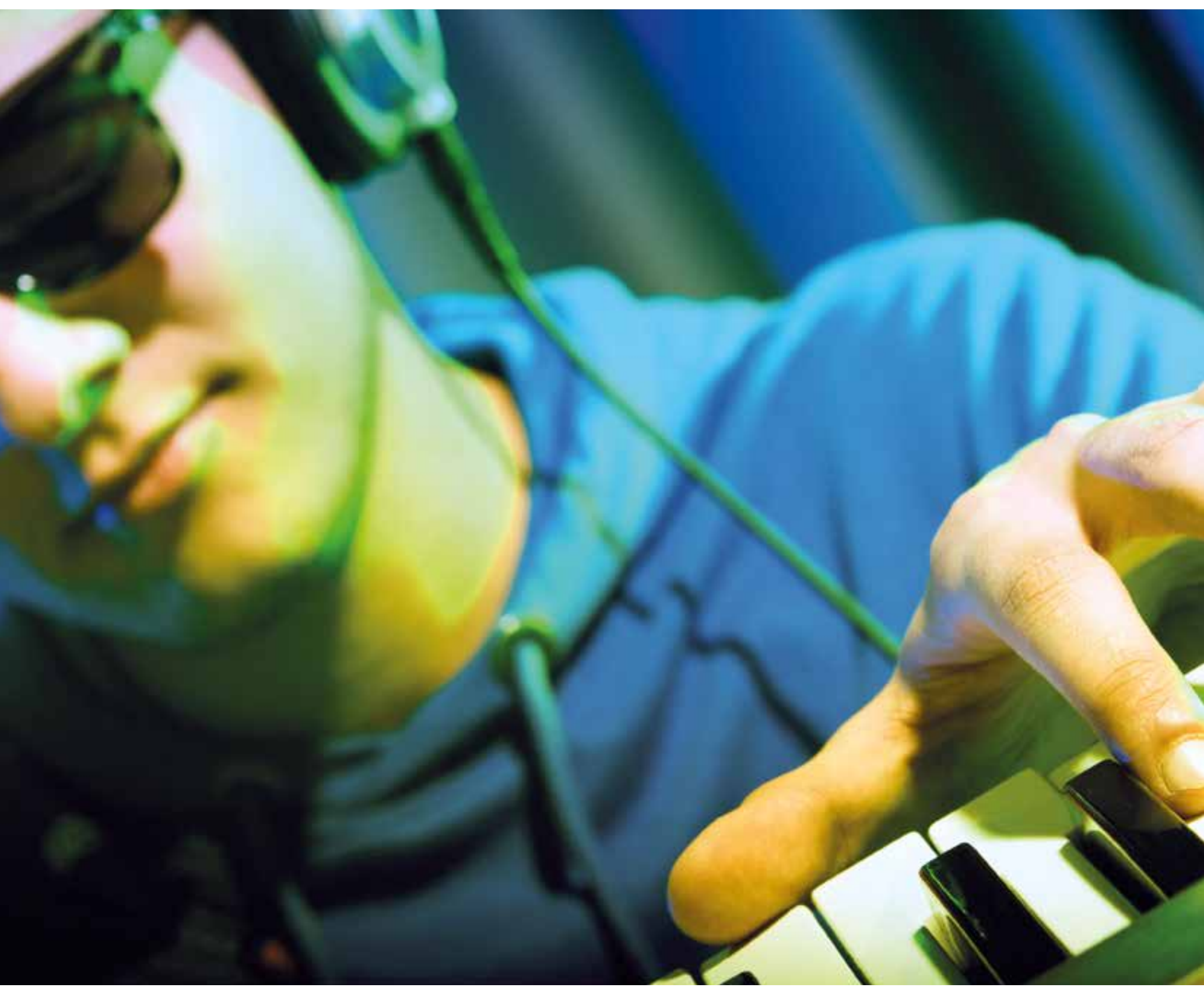




\section{Didaktiset periaatteet}

Jäljempänä esitetään joukko didaktisia periaatteita, joilla oppilaiden taitojen ja henkilökohtaisten ominaisuuksien kehittämistä voidaan tukea. Didaktiikassa on kyse opetuksen tavoitteiden, sisällön ja menetelmien välisestä yhteydestä, joka edistää oppimista ja myös tukee oppilaiden kehittymistä ja oppimisprosessia yleisesti. Didaktiset periaatteet ovat siis opettajan työkaluja opetuksen suunnittelussa ja ne vaikuttavat opetussuun- nitelman laatimiseen sekä opetuksen järjestämiseen ja toteuttamiseen. Periaatteiden ideana on se, että ne ovat riippumattomia luokka-asteesta, tasosta ja oppiaineista ja että ne helpottavat osaamistavoitteiden muuntamista käytännöksi ja päinvastoin. Periaatteita voidaan ottaa käyttöön yksitellen tai useita samanaikaisesti. Todennäköisesti ei kuitenkaan ole tarkoituksenmukaista tai mahdollista käyttää kaikkia periaatteita yhdellä kertaa.

\section{Toiminnallisen osaamisen kehittämistä tukevat periaatteet}

- Arvoa luova ${ }^{10} /$ muutoksiin johtava toiminta.

- Osallistava ja oppilaita aktivoiva työ.

- Vastuun antaminen oppilaille omasta toiminnasta.

- Tiedon ja taitojen soveltaminen eri konteksteissa.

- Toiminnan käynnistäminen erilaisista lähtökohdista.

- Verkostojen ja suhteiden hyödyntäminen.

- Erilaisten yhteistyötapojen edistäminen.

- Erilaisten esittelytapojen edistäminen.

- Opitun ja toiminnan välisen suhteen pohdinta.

\footnotetext{
${ }^{10}$ Arvonluonti erottaa yrittäjyyteen liittyvät oppimispolut muista prosessimaisista opetusmuodoista kuten ongelmakeskeisestä projektiopetuksesta tai teemaopetuksesta. Arvonluonnilla tarkoitetaan sitä, että toiminta tuottaa oppilaan oman oppimisen lisäksi lisäarvoa muille. Toisin sanoen toiminnasta saadaan yleismaailmallista hyötyä joko konkreettisten toimien muodossa tai potentiaalina kuten suunnitelmina tai malleina.
}

\author{
Luovan osaamisen kehittämistä \\ tukevat periaatteet \\ - Kokeellinen toiminta. \\ - Toiminnan järjestäminen ilman arviointia. \\ - Luova toiminta. \\ - Ajan varaaminen tiedon syventämiseen. \\ - Avointen/mahdottomien tehtävien \\ asettaminen. \\ - Yllättävä ja odottamaton toiminta. \\ - Useiden aistien käyttäminen. \\ - Oppilaiden kannustaminen pohtimaan \\ mielikuvituksen ja luovuuden yhteyttä.
}




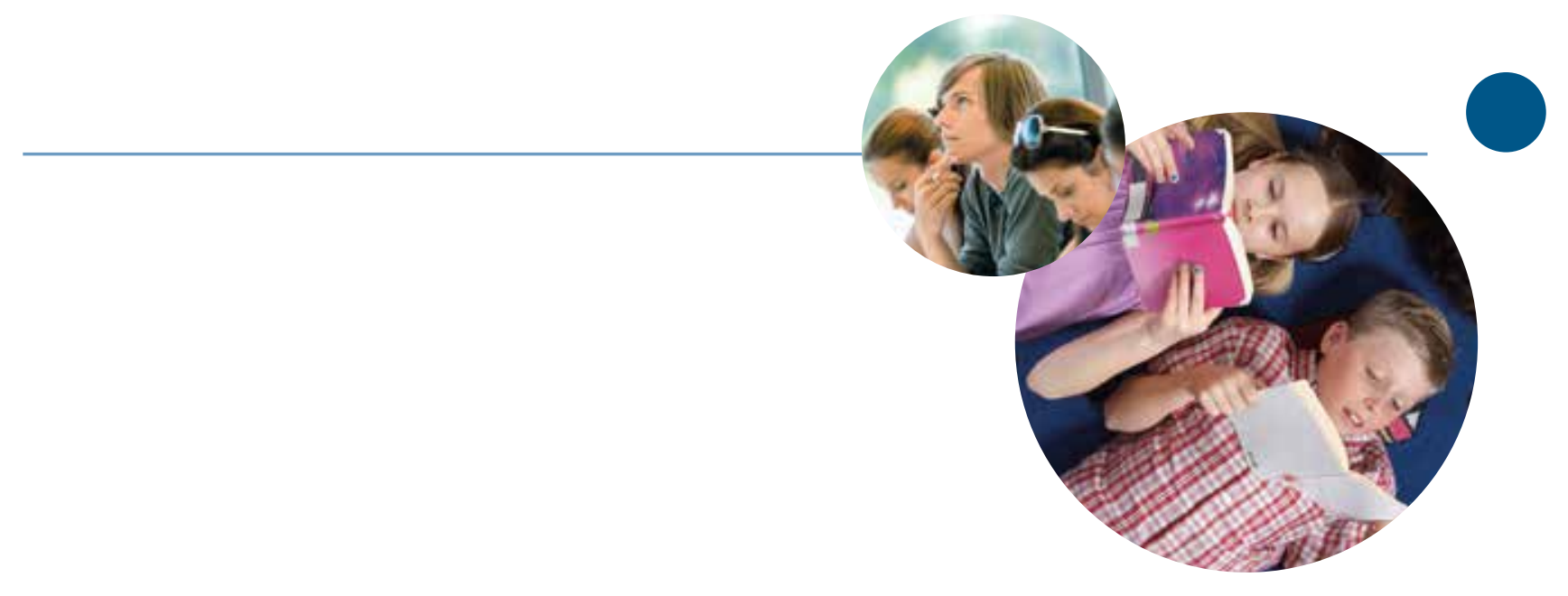

\section{Toimintaympäristöosaamisen kehittämistä} tukevat periaatteet

- Uteliaisuuden ja inmettelyn rohkaiseminen.

- Ajankohtaisten aiheiden käsittely.

- Osaamisen, tietojen ja taitojen näkeminen oikeissa mittasuhteissa.

- Sosiaalisten, taloudellisten ja kulttuuristen kontekstien huomioiminen.

- Yksilön, koulun ja toimintaympäristön välisen vuorovaikutuksen mahdollistaminen.

- Tiedon ja palautteen hakeminen ympäröivästä maailmasta.

- Maailman kuvaaminen mahdollisuutena.

- Opitun ja toiminnan välisen suhteen pohdintaan kannustaminen.

\section{Henkilökohtaisten ominaisuuksien kehittämistä tukevat periaatteet}

- Onnistumisen kokemusten tarjoaminen.

- Sopivan haastavien tehtävien asettaminen.

- Tilaa toiminnalle, josta saa tunnustusta.

- Epävarmuuden tietoinen käsittely.

- Oppilaiden osallistaminen ja aktivointi.

- Tuki ja ohjaus.

- Rohkaisu henkilökohtaisia ominaisuuksia koskevaa pohdintaan. 


\section{Esimerkkejä didaktisten periaatteiden käytöstä}

Esimerkit ovat ammattilaisten laatimia ja niitä on kokeiltu kouluissa Pohjoismaissa. Oppiaineet ja yleiset osaamistavoitteet on otettu opetuksen yhteisistä tavoitteista. Kyse on suhteellisen tavanomaisista opetusjaksoista, jotka tukevat sekä oppiainetavoitteiden saavuttamista sekä yrittäjäosaamista didaktisten periaatteiden käytön avulla.

\section{Luonnon monimuotoisuus, 3. luokka:}

Opetusjaksoon sisältyy luonnontieteiden opetusta koskevia tavoitteita mukaan lukien tutkiva työskentely ja viestintä.

Jakso aloitetaan selittämällä käsitettä luonnon monimuotoisuus. Tämän jälkeen oppilaat hakevat itsenäisesti tietoa eläimistä ja niiden elinympäristöistä eri tietokannoista (tiedon ja palautteen hakeminen ympäröivästä maailmasta). Seuraavaksi oppilaat ja opettaja suunnittelevat yhdessä opintoretken (oppilaiden osallistaminen ja aktivointi), jossa oppilaat etsivät pienryhmissä eläimiä lähiympäristöstä (uteliaisuuden ja ihmettelyn rohkaiseminen) keskittyen erityisesti lähialueen tunnettuihin elinympäristöihin ja eläimistöön (kontekstin huomiointi). Sitten oppilaat valitsevat jonkin eläimen ja etsivät siitä lisätietoa (tiedon syventäminen) sekä tekevät luonnoksia ja piirustuksia (useiden aistien käyttäminen) tarkoituksena valmistella esityksiä valitsemastaan eläimestä (epävarmuuden tietoinen käsittely). Oppilaiden pitäessä esityksiä muita oppilaita ohjeistetaan kehumaan ja esittämään parannuksia sekä ehdotuksia työn jatkamiseksi (tilaa toiminnalle, josta saa tunnustusta). Lopuksi keskustellaan siitä, kuinka oppilaat voivat edistää luonnon monimuotoisuutta omassa lähiympäristössään (maailman kuvaaminen mahdollisuutena).

\section{Kaverihuonekalu, 6. luokka}

Opetusjaksoon sisältyy käsityön ja muotoilun oppiaineiden tavoitteita mukaan lukien valmistelun, materiaalien ja muotoilun osaamisalueet.

Oppilaat saavat tehtäväksi tehdä "huonekalun", joka sopii kaverien kanssa yhdessäoloon. Opetusjakso alkaa huonekalujen historiaa, taustaa ja muotoilun kehitystä koskevilla opettajan esityksillä ja keskusteluilla, joissa huonekaluja tarkastellaan käyttöesineinä, tavaroina ja taideteoksina (osaamisen, tietojen ja taitojen näkeminen oikeissa mittasuhteissa). Oppilaat vierailevat tämän jälkeen huonekaluliikkeessä (mieluiten todellisuudessa, vaihtoehtoisesti virtuaalisesti) ja tutkivat muotoilua, materiaaleja ja ominaisuuksia (tiedon ja palautteen hakeminen ympäröivästä maailmasta/yksilön, koulun ja ympäristön välisen vuorovaikutuksen mahdollistaminen). Oppilaat valitsevat huonekalun tarkoituksena kuvata sitä kirjallisesti (tiedon ja taitojen soveltaminen eri konteksteissa). Tämän jälkeen oppilaat kehittelevät ideoita omiksi huonekaluiksi ottaen lähtökohdaksi sen, että huonekalu sopii ystävien kanssa yhdessä olemiseen ja yhdessä oppimiseen (avoimet /mahdottomat tehtävät). Sitten oppilaat rakentavat malleja huonekaluista kiinteässä mittakaavassa (useiden aistien käyttäminen) ja antavat toisilleen rakentavaa palautetta (toiminnan järjestäminen ilman arviointia). Lopuksi oppilaat tutkivat, miten mallista voisi tulla konkreettinen tuote ja miten tuotannon pohjalta voidaan perustaa yritys (opitun ja toiminnan välisen suhteen pohdiskelu). Viimeiseksi oppilaat laativat myyntipuheen tuotteelle ja harjoittelevat sen pitämistä. 


\section{norden}

Pohjoismaiden ministerineuvosto

Ved Stranden 18

DK-1061 Copenhagen K

www.norden.org

Pohjoismaiden ministerineuvosto on tehnyt monivaiheista työtä yrittäjähengen ja yrittäjyyskasvatuksen tukemiseksi Pohjoismaissa.

Osaamiskehys on suunnattu monille eri toimijoille. Se on tarkoitettu ennen kaikkea työvälineeksi opettajille ja käytännön työtä tekeville, jotka voivat löytää siitä osaamis- ja oppimistavoitteita sekä didaktisia periaatteita opetukseen. Osaamiskehystä voivat hyödyntää myös päätöksentekijät, jotka säätävät lakeja ja luovat puitteet yrittäjyyskasvatuksen toteuttamiselle. Se on suunnattu myös rehtoreille, joiden tehtävänä on huolehtia koulun rakenteiden toimivuudesta, luoda oppimisympäristöjä ja kehittää pedagogiikkaa siten, että yrittäjyyskasvatuksesta tulee kiinteä osa peruskoulua.

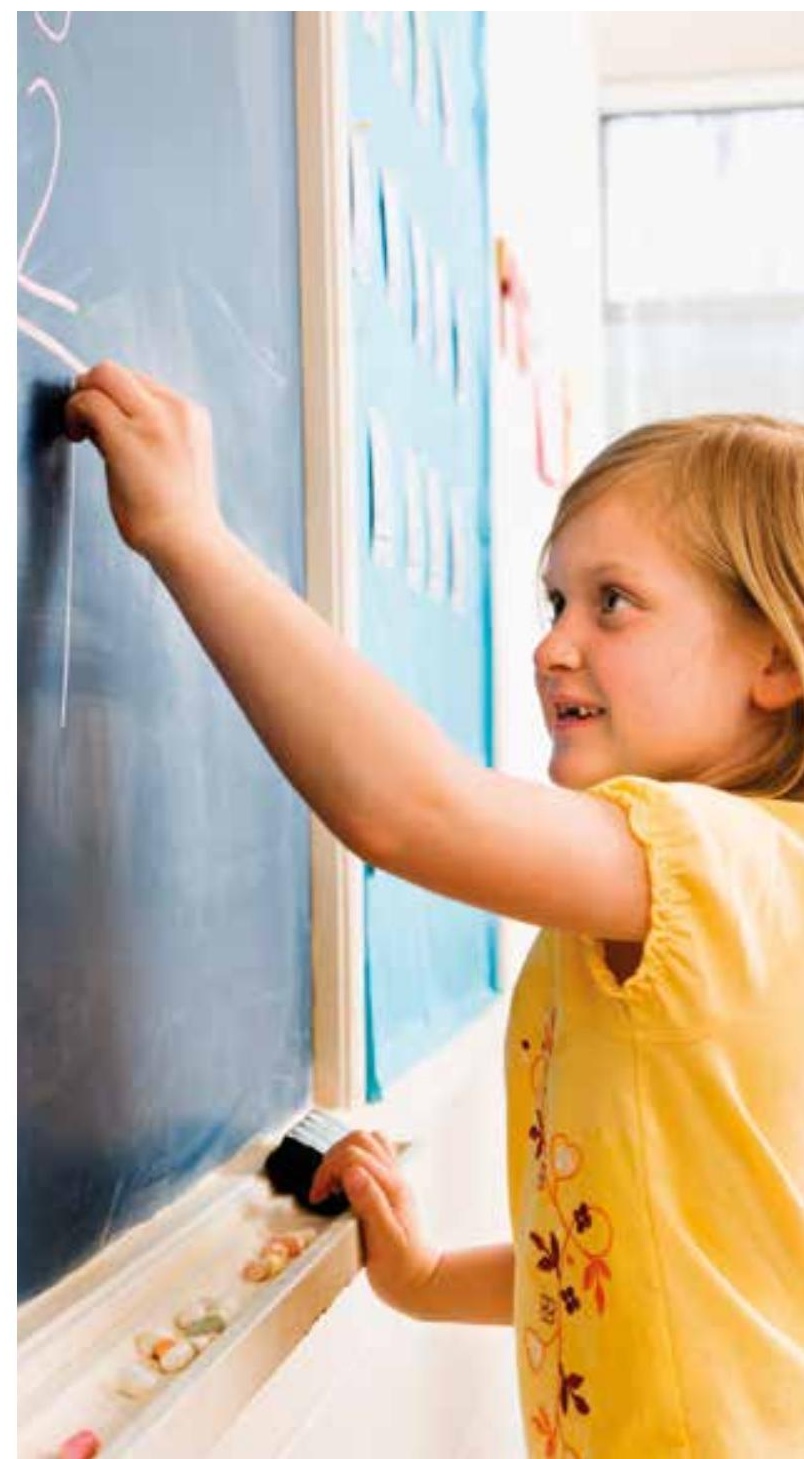

